\section{Por uma Presença mais Marcante da SBEM na Elaboração de Consensos de Interesse para o Endocrinologista}

$\mathrm{E}$ stamos completando nesta edição de Agosto de 1999 a publicação de uma série de cinco Consensos Brasileiros de temas de Endocrinologia e de áreas correlatas de interesse para a nossa especialidade. Há que se lamentar que o cronograma de revisão e atualização desses Consensos năo possa obedecer a uma agenda pré definida pelas várias especialidades, de maneira que pudessemos todos programar com certa antecedência a publicação da versão mais recente de cada um deles. Se assim fosse, talvez pudessemos contar, por exemplo com uma versão mais atual deste Consenso de Dislipidemias, que deverá ser atualizado somente em 2000. A versão que ora publicamos, embora seja a mais recente, foi elaborada há cerca de 3 anos. De certa maneira, o Consenso Brasileiro de Hipertensão também já está por merecer uma nova atualização, que deverá ser realizada também no ano que vem.

Temos recebido estímulos positivos pela iniciativa de publicarmos estes Consensos em números específicos da revista e, provavelmente, poderemos vir a faze-lo mais amiúde, na medida de manifestações de interesse dos leitores e/ou sempre que alguma nova publicação deste gênero puder ser oferecida espontaneamente, mesmo fora de qualquer cronograma, possibilitando sua publicação em números normais da revista.

Aproveito o ensejo para duas colocações que acredito importantes: em primeiro lugar é meu dever agradecer muitíssimo aos responsáveis pela elaboração e guarda deste material, a Sociedade Brasileira de Cardiologia, através de seus Departamentos de Hipertensão e de Aterosclerose, respectivamente por nos terem cedido as informações, as publicações originais e os respectivos disquetes dos Consensos de Hipertensão e de Dislipidemias. Nossos agradecimentos mais efusivos ao atual presidente da Sociedade Brasileira de Cardiologia, Dr. Rafael Leite Luna e aos Presidentes dos Departamentos de Hipertensão e Aterosclerose desta Sociedade, respectivamente Drs. Hilton de Castro Chaves Jr. e Jayme Diament, que tornaram possíveis esta empreitada. Gostaríamos, também, de agradecer às respectivas secretárias e demais pessoas envolvidas, que nos bastidores nos auxiliaram com a parte logística de todo o processo e, também, aos responsáveis iniciais pela idealização, organização e redação dos manuscritos originais, cujos nomes estão listados no preâmbulo de cada um dos Consensos.

Em segundo lugar, e motivo principal deste editorial, vejo-me instado a incentivar aqueles representantes de nossa Sociedade mais especificamente interessados ou envolvidos, para que participem de maneira mais ativa na elaboração e realização de futuros Consensos de interesse para o endocrinologista, como os de Osteoporose, Disfunção erétil, Climatério/ Reposição hormonal, além daqueles já referidos. Alguns deles tem sido conduzidos sob responsabilidade de Sociedades afins que não necessaria- editorial

\author{
Claudio E. Kater
}

Editor-Chefe, $A B E \mathcal{O} M$ 
mente convocam ou solicitam a participação de outras Sociedades, tornando estes "Consensos" mais restritos e muito menos consensuais.

Não é, ou não foi, entretanto, o caso dos dois Consensos aqui transcritos. No $2^{\mathrm{a}}$ Consenso de $\mathrm{Hi}-$ pertensão houve efetivamente um convite da Sociedade Brasileira de Cardiologia, corroborado pela Sociedade Brasileira de Hipertensão, para que enviássemos representantes, mas que, infelizmente, não motivou nenhuma posição de nossa parte, quer por aparente desinteresse ou descuido, que por uma agenda sobrecarregada. Tivemos, ainda assim, a participação efetiva de pelo menos uma endocrinologista, Dra. Maria Teresa Zanella, que estava envolvida no projeto deste sua concepção. Eu mesmo fora convidado por outras razões, mas encontrava-me, na ocasião, em viagem no exterior. Quanto ao Consenso de Dislipidemia, tivemos, conforme mostra a listagem de participantes a colaboração do Dr. Marcos A. Tambascia, em nome da SBEM, trazendo a palavra e a colaboração do endocrinologista e dando sustentação ao Consenso.

Acredito, assim, que devamos procurar estabelecer um canal de comunicação mais aberto e eficiente com as demais Sociedades, responsáveis que são pela convocação dos (sub) grupos para atualização dos Consensos e tornar nossa presença mais marcante e nossa colaboração mais efetiva. Devemos, talvez, até incentivar a formação de comissões supra societárias, de verdadeiros especialistas com vivência e experiência nos referidos temas, para que possam, em conjunto, formular as bases maiores para alicerçar verdadeiros consensos diagnósticos e terapêuticos sobre diversos temas específicos, que serão de fundamental importância para subsidiar as condutas médicas respectivas.

Por este mesmo raciocínio, acredito que nossas Sociedades afiliadas da FEBRASEM (Endocrinologia e Metabologia, Diabetes, Obesidade e Metabolismo Ósseo-Mineral) possam, também, tomar a iniciativa de convidar / convocar a participação de renomados e conceituados especialistas de outras Sociedades a colaborarem na concretização de Consensos que são, por tradição ou respeito, mantidos sob nossa fiança.

Esta atitude, já expressa em Consensos anteriores (Consenso Brasileiro para Deteç̧ão e Tratamento das Complicações Crônicas do Diabete Melito, para o qual participou o Conselho Brasileiro de Oftalmologia, e Consenso Brasileiro de Diabetes e Gravidez, que contou com o apoio da Federação Brasileira de Ginecologia e Obstetrícia ) tornará estas informações mais úteis, possivelmente melhor e mais amplamente divulgadas e menos confinadas a pequenos grupos ou círculos de interesses meramente comerciais.

Gostaria, assim, de colocar este assunto em pauta e obter alguma posição dos colegas para então propor, publicamente, às Comissões Organizadoras dos nossos próximos Congressos mais representativos (Endocrinologia e Metabologia, Diabetes, Obesidade e Metabolismo Ósseo), que uma ou mais sessões específicas sejam reservadas para este fim, estimulando o debate de diversos temas, especialmente os controversos, entre os colegas interessados. 